\title{
Cytological Responses of Garlic Root-tip Cells to Some Cigarette Smoke Constituents
}

\author{
R. C. Arnold, S. K. Mann, ${ }^{1}$ P. R. Bhalla, ${ }^{2}$ and \\ P. S. Sabharwal \\ T. H. Morgan School of Biological Sciences, University of Kentucky, \\ Lexington, Kentucky 40506, U.S.A.
}

Received June 30, 1976

There has been a strong desire among many who are devoted to the problem of tobacco smoke and its effects on human health to perfect a bioassay technique for cigarette smoke and its constituents so as to test their biological effects on living cells and tissues. Tobacco smoke is known to include a number of polycyclic aromatic compounds (Stedman 1968). Some of these are now known to be carcinogenic as determined by mouse skin bioassay technique (Wynder and Hoffman 1967). Nevertheless the vast majority of the chemical constituents of tobacco smoke have not been assayed, largely due to the time and expense involved in mouse skin bioassay procedure (Van Duuren 1975).

In this investigation, the mitotic events in root-tip cells of garlic (Allium sativum; family Liliaceae) were studied in an attempt to determine the feasibility of utilizing plant material in ascertaining the biological effects of selected cigarette constituents. Earlier work in this laboratory with cigarette smoke (Arnold et al. 1976) and smoke constituents, (Bhalla et al. 1974), demonstrated induction of mitotic abnormalities in cells of root-tip. The present investigation confirms earlier observations and is of a more comprehensive nature. It deals with the individual and combined effects of 1- and 2-naphthonitrile on cell division and chromosomes of root-tip cells of garlic.

\section{Materials and methods}

Commercially available garlic bulbs (Allium sativum; family Liliaceae) were grown in moist vermiculite at room temperature for 72 hours. At this time, the roots had emerged from the bulbs and were 2-3 centimeters in length. The bulbs were then placed into vials $(2 \mathrm{~cm} \times 5 \mathrm{~cm})$ containing various concentrations of 1-naphthonitrile and 2-naphthonitrile, as well as certain combinations of these chemicals for 24 hours. The structural formulae of these compounds are shown in Fig. 1. The concentrations utilized are given in Table 1.

A low concentration of dimethyl sulfoxide $(0.5 \%)$ was used as a solvent for making stock solutions of 1- and 2-naphthonitrile. The control roots were treated with double distilled water containing dimethyl sulfoxide equivalent to the amount used

I Division of Biosciences, Himachal Pradesh University, Summer Hill, Simla-5, India,

2 American Cyanamid Co., Agriculture Division, P. O. Box 400, Princeton, N. J., U. S. A. 
for making solutions of 1- and 2-naphthonitrile. Following treatment, the roots were fixed for 24 hours in a solution of $95 \%$ ethanol-acetic acid (3:1) at room temperature, they were then hydrolyzed in $1 \mathrm{~N} \mathrm{HCl}$ at $65^{\circ} \mathrm{C}$ for about 3 minutes. After hydrolysis, the roots were immediately washed several times with distilled water and stored in acetocarmine until squashes could be made from the apical $2 \mathrm{~mm}$. Twentyfive to thirty slides were made from each treatment. From these, three were finally selected on the basis of well spread cells and high mitotic index for detailed examination. The percentage of cells exhibiting mitotic abnormalities was recorded.<smiles>N#Cc1cccc2ccccc12</smiles>

\section{1-Naphthonitrile}<smiles>N#Cc1ccc2ccccc2c1</smiles>

\section{2-Naphthonitrile}

Fig. 1. Structural formulae of 1-naphthonitrile and 2-naphthonitrile.

\section{Results}

In control roots, $93 \%$ of the divided cells exhibited normal mitotic divisions. Nuclei of control cells at interphase were essentially spherical. In treated roots, the percentage of mitotic abnormalities was observed to increase significantly in relationship to the concentrations of the compounds utilized. Non-dividing cells of treated roots frequently showed pycnotic and elongated nuclei.

The concentrations utilized for studying the isolated effects of 1- and 2-naphthonitrile were $1,5,10,15,20$, and $25 \mathrm{ppm}$. Similar concentrations of the two compounds were used for studying their interactions. The most prevalent mitotic abnormalities induced by these chemicals individually and in combination were stickiness, chromosome breakage, chromosome bridging, lagging of individual chromosomes during anaphase, and the formation of micronuclei. However, when interactions of these compounds were studied, scattering of chromosomes, non-synchronization in the movements of chromosomes and polyploid cells were also observed.

The majority of the mitotic abnormalities seen were in metaphase cells. Table 1 summarizes the mitotic abnormalities at metaphase and anaphase in each treatment. From the table it is apparent that the overall effect of 2-naphthonitrile alone is about $4 \%$ more pronounced consistently than is 1-naphthonitrile in inducing abnormal mitotic divisions.

When the interactions of 1 - and 2-naphthonitrile were investigated, certain promotive effects of induction of mitotic abnormalities became apparent. Probably the most notable of these effects was that only $1 \mathrm{ppm}$ of 1 -naphthonitrile was observed to enhance the occurrence of mitotic abnormalities induced by all concentrations of 2-naphthonitrile by as much as $10 \%$. Five ppm of 1-naphthonitrile was also 
Table 1. Detailed observations of mitotic abnormalities induced by 1-naphthonitrile (1N) and 2-naphthonitrile (2N) and their interactions.

\begin{tabular}{|c|c|c|c|}
\hline Treatment & $\begin{array}{c}\text { Total } \\
\text { dividing cells }\end{array}$ & $\begin{array}{c}\text { Abnormally } \\
\text { dividing cells }(\%)\end{array}$ & $\begin{array}{c}\text { Mitotic } \\
\text { index }\end{array}$ \\
\hline $1 \mathrm{ppm} 1 \mathrm{~N}$ & 119 & 29.4 & 0.064 \\
\hline 5 ppm IN & 90 & 32.2 & 0.054 \\
\hline $10 \mathrm{ppm} \mathrm{1N}$ & 156 & 45.5 & 0.094 \\
\hline 15 ppm $1 \mathrm{~N}$ & 144 & 47.9 & 0.055 \\
\hline $20 \mathrm{ppm} \mathrm{1N}$ & 111 & 45.9 & 0.048 \\
\hline $25 \mathrm{ppm} 1 \mathrm{~N}$ & 129 & 72.1 & 0.050 \\
\hline 1 ppm $1 \mathrm{~N}+1$ ppm $2 \mathrm{~N}$ & 186 & 34.4 & 0.050 \\
\hline 5 ppm $1 \mathrm{~N}+1$ ppm $2 \mathrm{~N}$ & 133 & 44.4 & 0.049 \\
\hline $10 \mathrm{ppm} 1 \mathrm{~N}+1 \mathrm{ppm} 2 \mathrm{~N}$ & 120 & 51.7 & 0.039 \\
\hline 15 ppm $1 \mathrm{~N}+1 \mathrm{ppm} 2 \mathrm{~N}$ & 89 & 67.4 & 0.031 \\
\hline 20 ppm $1 \mathrm{~N}+1 \mathrm{ppm} 2 \mathrm{~N}$ & 100 & 68.0 & 0.036 \\
\hline 25 ppm $1 \mathrm{~N}+1$ ppm $2 \mathrm{~N}$ & 53 & 88.7 & 0.024 \\
\hline $1 \mathrm{ppm} 1 \mathrm{~N}+5 \mathrm{ppm} 2 \mathrm{~N}$ & 170 & 41.8 & 0.055 \\
\hline 5 ppm $1 \mathrm{~N}+5$ ppm $2 \mathrm{~N}$ & 138 & 53.0 & 0.055 \\
\hline $10 \mathrm{ppm} 1 \mathrm{~N}+5 \mathrm{ppm} 2 \mathrm{~N}$ & 135 & 70.4 & 0.057 \\
\hline $15 \mathrm{ppm} 1 \mathrm{~N}+5 \mathrm{ppm} 2 \mathrm{~N}$ & 111 & 71.2 & 0.048 \\
\hline 20 ppm $1 \mathrm{~N}+5 \mathrm{ppm} 2 \mathrm{~N}$ & 49 & 81.6 & 0.021 \\
\hline 25 ppm $1 \mathrm{~N}+5 \mathrm{ppm} 2 \mathrm{~N}$ & 12 & 81.7 & 0.010 \\
\hline $1 \mathrm{ppm} 2 \mathrm{~N}$ & 165 & 27.0 & 0.085 \\
\hline 5 ppm $2 \mathrm{~N}$ & 187 & 39.0 & 0.085 \\
\hline $10 \mathrm{ppm} 2 \mathrm{~N}$ & 174 & 44.2 & 0.088 \\
\hline $15 \mathrm{ppm} 2 \mathrm{~N}$ & 139 & 49.6 & 0.069 \\
\hline $20 \mathrm{ppm} 2 \mathrm{~N}$ & 96 & 58.3 & 0.054 \\
\hline 25 ppm $2 \mathrm{~N}$ & 66 & 80.3 & 0.037 \\
\hline 1 ppm $2 \mathrm{~N}+1$ ppm $1 \mathrm{~N}$ & 186 & 34.4 & 0.050 \\
\hline 5 ppm $2 \mathrm{~N}+1 \mathrm{ppm} 1 \mathrm{~N}$ & 170 & 41.8 & 0.055 \\
\hline $10 \mathrm{ppm} 2 \mathrm{~N}+1 \mathrm{ppm} 1 \mathrm{~N}$ & 173 & 42.8 & 0.052 \\
\hline 15 ppm $2 \mathrm{~N}+1 \mathrm{ppm} 1 \mathrm{~N}$ & 135 & 51.8 & 0.047 \\
\hline 20 ppm $2 \mathrm{~N}+1 \mathrm{ppm} 1 \mathrm{~N}$ & 114 & 65.8 & 0.035 \\
\hline $25 \mathrm{ppm} 2 \mathrm{~N}+1 \mathrm{ppm} 1 \mathrm{~N}$ & 78 & 67.9 & 0.038 \\
\hline 1 ppm $2 \mathrm{~N}+5$ ppm $1 \mathrm{~N}$ & 138 & 46.4 & 0.051 \\
\hline 5 ppm $2 \mathrm{~N}+5$ ppm $1 \mathrm{~N}$ & 138 & 55.1 & 0.055 \\
\hline 10 ppm $2 \mathrm{~N}+5 \mathrm{ppm} 1 \mathrm{~N}$ & 100 & 58.0 & 0.042 \\
\hline 15 ppm $2 \mathrm{~N}+5$ ppm $1 \mathrm{~N}$ & 66 & 60.6 & 0.031 \\
\hline 20 ppm $2 \mathrm{~N}+5$ ppm $1 \mathrm{~N}$ & 46 & 80.4 & 0.021 \\
\hline $25 \mathrm{ppm} 2 \mathrm{~N}+5 \mathrm{ppm} 1 \mathrm{~N}$ & 25 & 80.0 & 0.022 \\
\hline
\end{tabular}

found to have a similar effect as $1 \mathrm{ppm} 1$-naphthonitrile in association with 2-naphthonitrile. The overall effect of $1 \mathrm{ppm}$ of 2-naphthonitrile in presence with different concentrations of 1-naphthonitrile appeared less pronounced. These treatments had about $5 \%$ more mitotic abnormalities than did corresponding concentrations of 1-naphthonitrile. Five ppm of 2-naphthonitrile enhanced the overall effects of the different 1 -naphthonitrile treatments by about $11 \%$. The detailed effects of these interactions are shown in Fig. 2. The mitotic index, in general, 
declined when the roots were treated with higher concentrations of either 1- or 2naphthonitrile in isolation or in combination.

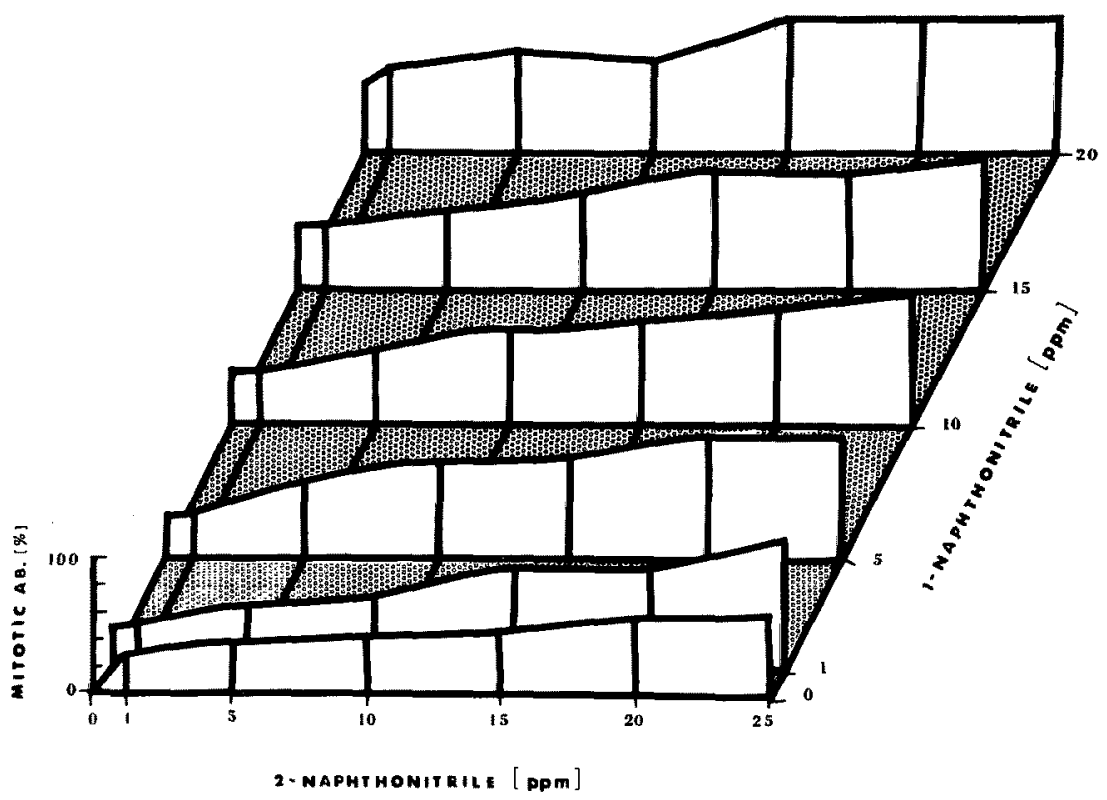

Fig. 2. Effect of various concentrations of 1- and 2-naphthonitrile alone and in combination at various levels on the mitotic abnormalities in the root-tips of garlic.

\section{Disscussion}

The present investigation demonstrates that 1-naphthonitrile and 2-naphthonitrile are quite capable of inducing mitotic abnormalities in dividing garlic cells. These observations are in general conformity with earlier work from this laboratory (Bhalla et al. 1974) and elsewhere (Izard et al. 1970). The present work was extended basically for noting possible interactions of 1- and 2-naphthonitrile. Low concentrations of either of these two analogues appear quite capable of enhancing the overall effects of the other on mitotic divisions of garlic cells.

Observations of meristematic plant cells are quite simple for the determination of the percent of mitotic abnormalities as well as the mitotic index. These two calculations may give the observer a quick, easy, and accurate indication of the relative overall potency of the compounds tested. These same parameters, however, would not necessarily indicate the relative carcinogenicity of these compounds to animal systems. Nevertheless, a bioassay technique such as the one employed in this investigation could conceivably be of value in ascertaining the tobacco smoke constituents which are most toxic to living cells. Presently, the mouse skin-painting technique (Van Duuren 1975) is the most commonly used bioassay for determining the relative carcinogenicity of cigarette smoke constituents. It is known to be expensive and time-consuming. All of the observations of this investigation were made within two weeks following the initial time when the garlic bulbs were allowed 
to germinate. Thus, the possibility of using plant material as a simple and efficient bioassay of tobacco smoke constituents should be further investigated. Such an assay might be of value in screening large numbers of samples rapidly and accurately for research. By this means, certain of the more potent chemical components of tobacco smoke might be determined and removed from tobacco before it is used for commercial products.

\section{Summary}

Root-tips of garlic (Allium sativum) were used to study the cytological effects of 1-naphthonitrile and 2-naphthonitrile in isolation and in combination. The treated interphase cells showed pycnotic and elongated nuclei. The mitotic abnormalities observed in treated root-tip cells included scattering of chromosomes, nonsynchronization in the movements of chromosomes, stickiness, chromosome breakage, bridges during anaphase, lagging of whole chromosomes, and the formation of micronuclei. Low concentrations of one compound appear capable of enhancing the overall effects of the other with respect to inducing mitotic abnormalities. The mitotic index was observed to decrease with increasing concentrations of either or both of these two constituents. It is suggested that this bioassay technique might be more economically feasible for preliminary rapid screening of the biological effects of tobacco smoke constituents from various cigarettes.

\section{Acknowledgement}

This study was carried out under contract No. 12-14-100-11004 (73) with the Agriculture Research Service, U.S. Department of Agriculture, administered by the Athens, Georgia Area, Richard B. Russell Agricultural Research Center, Athens, Georgia 30604.

\section{Literature Cited}

Arnold, R. C., Bhalla, P. R. and Sabharwal, P. S. 1976. Cytological responses of Allium sativum to smoke puffs from various types of cigarettes. Cytologia 41: 543-551.

Bhalla, P. R., Arnold, R. C. and Sabharwal, P. S. 1974. Cytological investigations on onion roottip cells treated with some cigarette smoke constituents. J. Hered. 65: 311-313.

Izard, C., Valadaud, D. and Morée-Testa 1970. Sur l'activité chromatoclasique et mitoclasique de certaines fractions de goudrons de fumeé de cigarette. C. R. Acad. Science. Paris 270: 2457-2459.

Stedman, R. L. 1968. The chemical composition of tobacco and tobacco smoke. Chem. Rev. 68: 153-207.

Van Duuren, B. L., Sivak, A., Katz, C., Seidman, I. and Melchoinne, S. 1975. The effect of aging and interval between primary and secondary treatment in two-stage carcinogenesis on mouse skin. Can. Res. 35 (3): 506-511.

Wynder, E. L. and Hoffman, D. 1967. Tobacco and Tobacco Smoke. Academic Press, New York, New York. 